\title{
Analisis Perbandingan Kinerja Keuangan Setelah Merger atau Akuisisi
}

\author{
Rizky Trinanda Akhbar ${ }^{1}$ \\ Sekolah Tinggi Ilmu Ekonomi Pandu \\ Madania, Indonesia
}

\author{
Ali Nurdin ${ }^{2}$ \\ Sekolah Tinggi Ilmu Ekonomi Pandu \\ Madania, Indonesia
}

\author{
Ulfa Siti Maspupah ${ }^{3}$ \\ Sekolah Tinggi Ilmu Ekonomi Pandu \\ Madania, Indonesia
}

Surel : akhbar.rizky@gmail.com

\begin{abstract}
ABSTRAK
Penelitian ini bertujuan untuk mengetahui kondisi kinerja keuangan perusahaan antara sebelum dan sesudah merger atau akuisisi. Objek dalam penelitian ini adalah kinerja keuangan perusahaan yang terdaftar di Bursa Efek Indonesia yang melakukan merger atau akuisisi tahun 2012. Tahun yang diteliti adalah 4 tahun sebelum 4 tahun sesudah merger atau akuisisi. Variabel yang diteliti adalah rasio profitabilitas (NPM, ROI, ROA dan ROE), rasio aktivitas (TATO dan FATO), rasio pasar (EPS dan PER), rasio likuiditas (CR dan QR) serta rasio solvabilitas (DR dan DER). Data yang digunakan adalah data sekunder. Metode penentuan sampel menggunakan metode non probability sampling dengan pendekatan purposive sampling. Teknik analisis data yang digunakan adalah uji statistik deskriptif. Hasil dari penelitian menunjukkan kinerja keuangan sebelum merger atau akuisisi dikatakan berfluktuatif sedangkan sesudah merger atau akuisisi cenderung menurun.
\end{abstract}

Kata Kunci: Akuisisi; Kinerja Keuangan; Merger.

\section{Comparative Analysis of Financial Performance After Merger or Acquisition}

\section{ABSTRACT}

This study aims to investigate the company's financial performance before and after a merger or acquisition process. The research focuses on the financial performance of companies listed in Indonesia Stock Exchange that did a merger or acquisition in 2012. Secondary data from financial statements was collected and analyzed for four years before and four years after the merger or acquisition. The variables examined are profitability ratios (NPM, ROI, ROA and ROE), activity ratios (TATO and FATO), market ratios (EPS and PER), liquidity ratios (CR and $Q R$ ) and solvency ratios (DR and DER). Non probability sampling method with a purposive sampling approach is used to determine the samples of this study. Using descriptive statistical test we find that financial performance before a merger or acquisition is fluctuating while after a merger or acquisition tends to decline. In other words, merger and acquisition not effective yet to improve company's financial performance.

Keywords: Acquisition; Financial Performance; Merger.

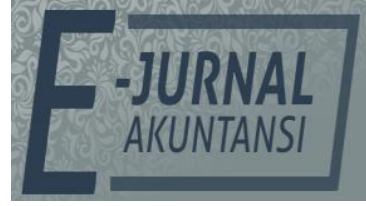

e-ISSN 2302-8556

Vol. 31 No. 4

Denpasar, April 2021

Hal. 966-976

DOI:

10.24843/EJA.2021.v31.i04.p13

PENGUTIPAN

Akhbar, R.T., Nurudin, A., \& Maspupah, U.S. (2021). Analisis Perbandingan Kinerja Keuangan Setelah Merger atau Akuisisi. EJurnal Akuntansi, 31(4), 966-

976

RIWAYAT ARTIKEL:

Artikel Masuk: 24 Agustus 2020 Artikel Diterima: 24 April 2021

Artikel dapat diakses : https://ojs.unud.ac.id/index.php/Akuntansi/index 


\section{PENDAHULUAN}

Persaingan yang ketat menuntut perusahaan untuk dinamis dan reaktif terhadap perubahan-perubahan yang terjadi. Keputusan yang strategis harus dapat diambil untuk dapat bertahan di tengah kompetisi yang semakin ketat. Berbagai cara dilakukan perusahaan untuk dapat meningkatkan kinerja atau minimal mempertahankan posisinya. Di antara strategi yang diambil adalah melakukan merger atau akuisisi.

Merger dan akuisisi telah dilakukan sejak lama dan hingga saat ini masih dipandang sebagai salah satu strategi yang dapat ditempuh perusahaan dalam mencapai tujuannya. Di tahun 1990-an terjadi merger dan akuisisi dalam jumlah yang besar di seluruh dunia, terutama pada perusahaan yang bergerak di bidang keuangan dan perbankan, telekomunikasi, hiburan, media dan juga teknologi informasi (Motis, 2007). Di era tersebut terjadi akuisisi dengan nilai transaksi terbesar yaitu akuisisi yang dilakukan oleh Vodafone AirTouch PLC terhadap Mannesmann AG dengan nilai transaksi sebesar 202,7 bil.USD pada tahun 1999. Nilai tersebut hingga saat ini masih merupakan yang tertinggi di dunia. Jumlah terbesar merger dan akuisisi terjadi pada tahun 2017, dimana terdapat 52.740 transaksi untuk merger dan akuisisi di seluruh dunia, jumlah ini meningkat sekitar 100\% jika dibandingkan transaksi yang terjadi di tahun 1997 (IMAA, 2020).

Peraturan Pemerintah Republik Indonesia No. 27 Tahun 1988 mendefinisikan merger adalah perbuatan hukum yang dilakukan oleh satu perseroan atau lebih untuk menggabungkan diri dengan perseroan lain yang telah ada dan selanjutnya perseroan yang menggabungkan diri menjadi bubar. Ikatan Akuntan Indonesia memberikan definisi berdasarkan perspektif akuntansi bahwa merger adalah salah satu metode penyatuan usaha (business combination). Penyatuan usaha itu sendiri didefinisikan sebagai penyatuan dua atau lebih perusahaan yang terpisah menjadi satu entitas ekonomi karena adanya penyatusan tersebut atau memperoleh kendali atas aktiva dan operasi perusahaan lain. Dari definisi tersebut akuntansi membedakan penyatuan usaha dalam dua kategori yaitu: (1) Penyatuan kepentingan atau penyatuan kepemilikan serta (2) Akuisisi (Laiman \& Hatane, 2017).

Akuisisi berasal dari kata acquisition atau acquisition. Secara harfiah akuisisi mempunyai makna membeli atau mendapatkan sesuatu obyek untuk ditambahkan pada obyek yang telah dimiliki sebelumnya. Dalam PSAK No.22 mendefinisikan akuisisi sebagai suatu penggabungan usaha dimana salah satu perusahaan yaitu pengakuisisi memperoleh kendali atas aktiva dan operasi perusahaan yang diambil alih. Biasanya perusahaan pengakuisisi memliki ukuran yang lebih besar dibandingkan dengan perusahaan terakuisisi. Akuisisi berbeda dengan merger karena akuisisi tidak menyebabkan pihak lain bubar sebagai entitas hukum (Laiman \& Hatane, 2017).

Terdapat beberapa alasan perusahaan memutuskan untuk menjalankan strategi merger atau akuisisi. Harari (1997) menyebutkan bahwa sinergi, skala ekonomis, penghematan biaya, meningkatkan produk dan rasionalisasi saluran distribusi adalah beberapa motif yang mendasari. Albizzatti \& Sias (2004) berpendapat bahwa alasan yang mendasari akuisisi adalah untuk mendapatkan produk baru, meningkatkan keahlian dan kemampuan, memperluas area 
geografis, konsolidasi dengan pelaku industri lain yang lebih matang, serta transformasi ke arah industri yang lebih maju. Selain itu, dalam jangka panjang juga dapat meningkatkan nilai perusahaan (Van Horne \& Wachowicz Jr, 2013), meskipun untuk kasus di Indonesia merger dan akuisisi tidak berdampak signifikan terhadap peningkatan nilai perusahaan (Perwito et al., 2020).

Seperti halnya strategi pada umumnya, perusahaan menghadapi risiko dalam setiap keputusan yang diambil, begitu juga dengan merger dan akuisisi. mengemukakan bahwa merger yang dilakukan dengan perusahaan domestik memberikan dampak positif terhadap kinerja keuangan, sedangkan apabila dilakukan dengan perusahaan luar negeri akan sedikit memberikan dampak negatif. Merger dan akuisisi yang dilakukan dengan perencanaan yang baik akan memberikan hasil positif (Bolbanabad et al., 2017). Tipe merger dan akuisisi yang dipilih juga dapat memberikan hasil yang berbeda terhadap kesuksesan perusahaan (Rozen-Bakher, 2018).

Visi yang lemah dari pimpinan perusahaan juga dapat menjadi penyebab kegagalan proses ini (Harari, 1997). Sejalan dengan itu, Gadiesh et al. (2003) menyebutkan strategi yang lemah, perbedaan budaya, kesulitan dalam komunikasi, lemahnya perencanaan dan eksekusi, dan terlalu terfokus pada target perusahaan dapat membawa kegagalan dalam merger dan akuisisi. Kinerja keuangan terutama dari aspek profitabilitas perusahaan, merger dan akuisisi memberikan dampak laba yang tidak konsisten (Akben-Selcuk \& Altiok-Yilmaz, 2011), tidak ada perbedaan yang signifikan setelah perusahaan melakukan merger dan akuisisi (Mahesh \& Prasad, 2012; Laiman \& Hatane, 2017; Setiawan \& Rasmini, 2018; Zuhri et al., 2020) bahkan memberikan efek negatif yang signifikan (Oduro \& Agyei, 2013; Yeh \& Hoshino, 2002). Bertentangan dengan pernyataan tersebut, terdapat beberapa penelitian yang menunjukkan dampak positif baik dari sisi keuangan (Ismail et al., 2011; Gugler et al., 2003; Ahmed et al., 2018) maupun dari sisi operasional perusahaan (Lau et al., 2008).

Di Indonesia, pelaksanaan merger dan akuisisi diatur dalam Undangundang Republik Indonesia Nomor 40 tahun 2007 tentang Perseroan Terbatas. Lebih lanjut, Badan Pengawas Pasar Modal mengeluarkan aturan Keputusan Ketua Badan Pengawas Pasar Modal Nomor KEP-52/PM/1997 tentang Penggabungan Usaha atau Peleburan Usaha Perusahaan Publik atau Emiten, sedangkan terkait akuisisi terbit Peraturan Otoritas Jasa Keuangan Nomor 9/POJK.04/2018 tentang Pengambilalihan Perusahaan Terbuka. Sebagai pedoman dalam penyajian laporan keuangan, Ikatan Akuntan Indonesia (IAI) menerbitkan Pernyataan Standar Akuntansi Keuangan (PSAK) 22 tentang Kombinasi Bisnis.

Kinerja merupakan analisis data serta pengendalian bagi perusahaan. Pengukuran kinerja digunakan perusahaan untuk melakukan perbaikan diatas kegiatan operasionalnya agar dapat bersaing dengan perusahaan lain. Bagi investor informasi mengenai kinerja perusahaan dapat digunakan untuk melihat apakah mereka akan mempertahankan investasi mereka di perusahaan tersebut atau mencari alternatife lain (Laiman \& Hatane, 2017).

Berdasarkan data dari Komisi Pengawas Persaingan Usaha (KPPU) jumlah perusahaan yang melakukan merger maupun akuisisi di Indonesia dalam periode 2010-2015 dapat dilihat pada Tabel 1. 
Tabel 1. Notifikasi Penggabungan Usaha Tahun 2010-2015

\begin{tabular}{cccc}
\hline Tahun & Merger & Akuisisi & Jumlah \\
\hline 2010 & 0 & 3 & 3 \\
2011 & 0 & 43 & 43 \\
2012 & 1 & 34 & 35 \\
2013 & 1 & 69 & 70 \\
2014 & 1 & 53 & 54 \\
2015 & 3 & 34 & 37 \\
\hline
\end{tabular}

Sumber: KPPU, 2017

Berdasarkan informasi tersebut, untuk mengetahui apakah aktivitas merger atau akuisisi tersebut memberikan dampak yang positif pada kinerja keuangan perusahaan, maka dilakukan penelitian lebih lanjut untuk mengetahui kondisi keuangan perusahaan antara periode 4 (empat) tahun sebelum dan 4 (empat) tahun sesudah adanya aktivitas merger atau akuisisi tersebut. Sepanjang pengetahuan penulis, belum ada peneliti lain yang melakukan penelitian terkait kinerja keuangan perusahaan di Indonesia yang dihasilkan dari terjadinya proses merger dan akuisisi dalam kurun waktu yang sama.

\section{METODE PENELITIAN}

Objek penelitian ini adalah kinerja keuangan perusahaan yang melakukan merger atau akuisisi pada tahun 2012 yang terdaftar di Bursa Efek Indonesia. Kinerja keuangan yang diteliti adalah kinerja keuangan perusahaan pengakuisisi dan perusahaan yang hidup dari adanya aktivitas merger periode waktu 4 (tahun) sebelum melakukan merger atau akuisisi, yakni tahun 2008 hingga tahun 2011 serta 4 (empat) tahun sesudah melakukan merger atau akuisisi, yakni tahun 2013 hingga 2016. Kinerja keuangan yang diteliti adalah rasio profitabilitas, rasio aktivitas, rasio pasar, rasio likuiditas dan rasio solvalibitas.

Rasio profitabilitas digunakan untuk mengukur kemampuan perusahaan dalam menghasilkan keuntungan untuk perusahaan. Indikator pengukuran menggunakan rasio Net Profit Margin, Return on Investment, Return on Assets, dan Return on Equity. Rasio aktivitas merupakan rasio yang digunakan untuk mengukur efektivitas perusahaan dalam menggunakan aktiva yang dimiliknya. Indikator pengukuran menggunakan rasio Total Assets Turn Over dan Fixed Assets Turn Over. Rasio pasar merupakan rasio yang mengukur bagaimana nilai perusahaan saat ini dan dimasa yang akan datang. Indikator pengukuran menggunakan rasio Earning per Share dan Price Earning Ratio. Rasio likuiditas merupakan rasio yang menggambarkan kemampuan perusahaan dalam memenuhi kewajiban (hutang) jangka pendek. Indikator pengukuran menggunakan Current Ratio dan Quick Ratio. Rasio solvabilitas merupakan rasio yang digunakan untuk mengukur sejauh mana aktiva perusahaan dibiayai dengan hutang. Indikator pengukuran menggunakan Debt Ratio dan Debt to Equity Ratio.

Penelitian ini menggunakan data sekunder yang bersifat kuantitatif dan kualitatif. Metode penentuan sampel pada penelitian ini adalah teknik non probability sampling dengan pendekatan purposive sampling dengan kriteria sebagai berikut, Perusahaan pengakuisisi atau perusahaan yang menerima penggabungan usaha melalui merger merupakan perusahaan go public terdaftar 
di BEI. Melakukan aktivitas merger atau akuisisi pada periode tahun 2012. Waktu merger atau akuisisi diketahui dengan jelas. Tersedia laporan keuangan yang telah diaudit untuk 4 (empat) tahun sebelum dan 4 (empat) tahun sesudah aktivitas merger atau akuisisi. Laporan keuangan tersedia dalam satuan rupiah.

Berdasarkan kriteria tersebut diperoleh lima perusahaan yang memenuhi kriteria untuk digunakan sebagai sampel dari total 35 perusahaan yang melakukan merger atau akuisisi pada tahun 2012. Daftar perusahaan tersebut dapat dilihat pada Tabel 2.

\section{Tabel 2. Daftar Perusahaan Sampel}

\begin{tabular}{lllcl}
\hline No & $\begin{array}{l}\text { Perusahaan } \\
\text { Pengakuisisi/Perusahaan } \\
\text { yang Menerima Merger }\end{array}$ & $\begin{array}{l}\text { Perusahaan } \\
\text { Target/Perusahaan } \\
\text { Sasaran }\end{array}$ & $\begin{array}{l}\text { Waktu } \\
\text { Merger atau } \\
\text { Akuisisi }\end{array}$ & Ket \\
\hline 1 & PT Kalbe Farma, Tbk & $\begin{array}{l}\text { PT Hale } \\
\text { International }\end{array}$ & 21-Jun-2012 & Akuisisi \\
2 & PT Tunas Ridean, Tbk & $\begin{array}{l}\text { PT Rahardja } \\
\text { Ekalancar }\end{array}$ & 28-Jun-2012 & Akuisisi \\
3 & PT Holcim Indonesia Tbk & $\begin{array}{l}\text { PT Semen Dwima } \\
\text { Agung }\end{array}$ & 30-Jun-2012 & Merger \\
4 & PT Alam Sutera Realty, Tbk & $\begin{array}{l}\text { PT Garuda } \\
\text { Adhimatra Indonesia }\end{array}$ & 30-Jul-2012 & Akuisisi \\
& & $\begin{array}{l}\text { PT Plaza Adika } \\
\text { Lestari }\end{array}$ & 28-Des-2012 & Akuisisi \\
& $\begin{array}{l}\text { PT Cowell Development, } \\
\text { Tbk }\end{array}$ & & & \\
\hline
\end{tabular}

Sumber : Data Penelitian, 2018

Teknik analisis data yang digunakan adalah analisis statistik deskriptif, untuk mendeskripsikan atau memberi gambaran pada objek yang diteliti serta membuat kesimpulan dari data tersebut. Data diolah menggunakan perangkat lunak SPSS 20.

\section{HASIL DAN PEMBAHASAN}

Hasil statistik deskriptif kinerja keuangan perusahaan sebelum dan sesudah merger atau akuisisi menunjukkan bahwa setelah perusahaan melakukan merger atau akuisisi masing-masing rasio pada 5 (lima) perusahaan tersebut juga berfluktuatif. Rata-rata untuk rasio Net Profit Margin pada 4 (empat) tahun sesudah perusahaan melakukan merger atau akuisisi yakni tahun 2013 hingga tahun 2016 adalah sebesar 9,24, Return on Investment sebesar 1.336,92, Return on Asset sebesar 6,42, Return on Equity sebesar 10,52, Total Asset Turn Over sebesar 0,99, Fixed Asset Turn Over sebesar 3,41, Earning per Share sebesar 39,23, Price Earning Ratio sebesar 5,64, Current Ratio sebesar 148,80, Quick Ratio sebesar 41,40, Debt Ratio sebesar 0,48 dan Debt to Equity Ratio sebesar 1,09. Hasil penelitian ini sejalan dengan penelitian yang menyatakan kinerja keuangan terutama dari aspek profitabilitas perusahaan, merger dan akuisisi memberikan dampak laba yang tidak konsisten (Akben-Selcuk \& Altiok-Yilmaz, 2011), tidak ada perbedaan yang signifikan setelah perusahaan melakukan merger dan akuisisi (Mahesh \& Prasad, 2012; Laiman \& Hatane, 2017; Setiawan \& Rasmini, 2018; Zuhri et al., 2020) bahkan memberikan efek negatif yang signifikan (Oduro \& Agyei, 2013; Yeh \& Hoshino, 2002). 
Tabel 9. Penilaian Kinerja Keuangan Persusahaan Sesudah Merger atau Akuisisi

\begin{tabular}{lllll}
\hline Rasio & Rata-rata & Standar & Capaian & Penilaian \\
\hline NPM $(\%)$ & 9,24 & 20 & 46,20 & Di bawah standar \\
ROI $(\%)$ & $1.336,92$ & 30 & $4.456,20$ & Di atas standar \\
ROA (\%) & 6,42 & 30 & 21,40 & Di bawah standar \\
ROE $(\%)$ & 10,52 & 40 & 26,30 & Di bawah standar \\
TATO (X) & 0,99 & 5 & 19,80 & Di bawah standar \\
FATO $(X)$ & 3,41 & 2 & 170,50 & Di atas standar \\
EPS (Rp) & 39,23 & 5,4 & 728,48 & Di atas standar \\
PER $(X)$ & 5,64 & 11,3 & 49,91 & Di bawah standar \\
CR $(\%)$ & 148,80 & 200 & 74,40 & Di bawah standar \\
QR $(\%)$ & 41,40 & 150 & 27,60 & Di bawah standar \\
DR $(X)$ & 0,48 & 0,35 & 137,14 & Di atas standar \\
DER $(X)$ & 1,09 & 0,90 & 121,11 & Di atas standar \\
\hline
\end{tabular}

Sumber: Data Penelitian, 2018

Jika dibandingkan dengan kinerja keuangan perusahaan sebelum melakukan merger atau akuisisi maka terjadi penurunan pada masing-masing rasio seperti rasio profitabilitas yang dilihat dari indikator rasio Net profit Margin sebesar -4,67 yang sebelumnya sebesar 13,91 menjadi 9,24, hal ini mengindikasikan bahwa perusahaan belum mampu meningkatkan laba atas penjualan setelah adanya aktivitas merger atau akuisisi.

Return on Investment menurun sebesar 369,74 yang sebelumnya sebesar 1.706,66 menjadi 1.336,92, hal ini mengindikasikan bahwa perusahaan belum mampu meningkatkan laba atas penggunaan investasi yang dilakukan oleh perusahaan. Return on Asset menurun sebesar 3,04 yang sebelumnya sebesar 9,46 menjadi 6,42, hal ini mengindikasikan bahwa perusahaan belum mampu meningkatkan laba atas penggunaan dan pengelolaan aset ataupun aktivanya dan Return on Equity juga menurun sebesar -6,20 yang sebelumnya sebesar 16,70 menjadi 10,50, hal ini mengindikasikan bahwa perusahaan belum mampu meningkatkan laba atas ekuitas ataupun modal yang dimilikinya. Penelitian Laiman \& Hatane, (2017) menyatakan perbedaan yang signifikan Return On Assets sebelum dan sesudah aktivitas merger. Hasil ini sejalan dengan penelitian yang dilakukan Setiawan \& Rasmini, (2018) menyatakan perusahaan belum mampu memaksimalkan potensi tambahan modal yang diperoleh pasca merger dan akuisisi dalam jangka pendek.

Rasio aktivitas yang dilihat melalui indikator rasio Total Asset Turn Over dan Fixed Asset Turn Over juga menurun masing- masing sebesar -0,08 dan -9,82. Sebelumnya nilai Total Asset Turn Over sebesar 1,07 dan setelah perusahaan melakukan merger atau akuisisi nilai Total Asset Turn Over menurun menjadi 0,99. Laiman \& Hatane, (2017) terdapat perbedaan yang signifikan total assets turn over 
sebelum dan sesudah aktivitas merger. Begitu pula dengan nilai Fixed Asset Turn Over yang sebelumnya sebesar 13,23 menjadi 3,41. Hal ini mengindikasikan bahwa perusahaan belum mampu meningkatkan laba yang berasal dari aktiva tetap dan total aktiva yang dimiliki untuk menciptakan penjualan. Hasil ini sejalan dengan penelitian yang dilakukan Setiawan \& Rasmini, (2018) menyatakan perusahaan belum mampu memaksimalkan potensi tambahan modal yang diperoleh pasca merger dan akuisisi dalam jangka pendek.

Rasio pasar yang diukur melalui Earning per Share dan Price Earning Ratio juga menurun. Sebelumnya rasio Earning per Share sebesar 75,52, menurun sebesar -36,29 menjadi 39,23 dan sebelumnya rasio Price Earning Ratio sebesar 15,67 menurun sebesar -10,3 menjadi 5,64. Laiman \& Hatane, (2017) menyatakan terdapat perbedaan yang signifikan Price Earnings Ratio sebelum dan sesudah aktivitas merger. Hal ini mengindikasikan bahwa perusahaan belum mampu meningkatkan laba dan harga saham yang beredar.

Penurunan rasio juga terjadi pada rasio likuiditas yang diukur melalui Current Ratio dan Quick Ratio juga menurun. Current Ratio menurun sebesar 55,26 yang sebelumnya sebesar 204,06 menjadi 148,80 dan Quick Ratio menurun sebesar -73,27 yang sebelumnya sebesar 114,67 menjadi 41,40. Hal ini mengindikasikan bahwa kemampuan perusahaan dalam memenuhi kewajiban (hutang) jangka pendek juga menurun. Hasil ini sejalan dengan penelitian yang dilakukan Setiawan \& Rasmini, (2018) menyatakan perusahaan belum mampu memaksimalkan potensi tambahan modal yang diperoleh pasca merger dan akuisisi dalam jangka pendek.

Tabel 12. Perbandingan Capaian Kinerja Keuangan Sebelum dan Sesudah Merger atau Akuisisi

\begin{tabular}{lllll}
\hline Rasio & $\begin{array}{l}\text { Capaian } \\
\text { Sebelum }\end{array}$ & $\begin{array}{l}\text { Capaian } \\
\text { Sesudah }\end{array}$ & Selisih & Keterangan \\
\hline NPM (\%) & 69,55 & 46,20 & 23,35 & Turun \\
ROI (\%) & $5.688,87$ & $4.456,20$ & $1.232,67$ & Turun \\
ROA (\%) & 31,53 & 21,40 & 10,13 & Turun \\
ROE $(\%)$ & 41,75 & 26,30 & 15,45 & Turun \\
TATO $(X)$ & 21,40 & 19,80 & 1,60 & Turun \\
FATO $(X)$ & 661,50 & 170,50 & 491,00 & Turun \\
EPS (Rp) & $1.398,52$ & 728,48 & 670,04 & Turun \\
PER $(X)$ & 138,67 & 49,91 & 88,76 & Turun \\
CR $(\%)$ & 102,03 & 74,40 & 27,63 & Turun \\
QR $(\%)$ & 76,45 & 27,60 & 48,85 & Turun \\
DR $(X)$ & 122,86 & 137,14 & 14,28 & Naik \\
DER $(X)$ & 97,79 & 121,11 & 23,32 & Naik \\
\hline
\end{tabular}

Sumber: Data Penelitian, 2018

Berbeda dengan rasio lainnya yang menurun, rasio solvabilitas yang diukur melalui Debt Ratio dan Debt Equity Ratio justru meningkat masing-masing 0,05 dan 0,21 . Sebelumnya nilai Debt Ratio sebesar 0,43 dan setelah adanya merger atau akuisisi meningkat menjadi 0,48 dan untuk nilai Debt Equity Ratio 
sebelumnya sebesar 0,88 menjadi 1,09 . Peningkatan nilai tersebut bukan berarti kinerja perusahaan semakin baik melainkan terjadi penurunan kinerja keuangan hal ini mengindikasikan bahwa porsi aktiva yang dibiayai oleh hutang yang berasal dari kreditor juga meningkat dan mengancam ekuitas yang dimiliki perusahaan untuk menjamin hutang perusahaan. Semakin kecil rasio ini maka kinerja perusahaan semakin baik. Hasil ini sejalan dengan penelitian yang dilakukan Setiawan \& Rasmini, (2018) menyatakan perusahaan belum mampu memaksimalkan potensi tambahan modal yang diperoleh pasca merger dan akuisisi dalam jangka pendek.

\section{SIMPULAN}

Berdasarkan pembahasan tersebut dapat disimpulkan bahwa secara umum kinerja keuangan perusahaan setelah adanya merger atau akuisisi cenderung menurun. Penurunan kinerja keuangan perusahaan tersebut mengindikasikan bahwa manfaat yang dihasilkan dari adanya aktivitas merger atau akuisisi belum dapat dirasakan oleh perusahaan dalam kurun waktu 4 (empat) tahun setelah perusahaan melakukan aktivitas merger atau akuisisi. Hal ini dapat terlihat sebelum dilakukan aktivitas merger atau akuisisi, kondisi kinerja keuangan perusahaan yang diwakili oleh Net Profit Margin (NPM), Return on Investment (ROI), Return on Asset (ROA), Return on Equity (ROE), Total Asset Turn Over (TATO), Fixed Asset Turn Over (FATO), Earning Per Share (EPS), Price Earning Ratio (PER), Current Ratio (CR), Quick Ratio (QR), Debt Ratio (DR) dan Debt to Equity Ratio (DER) menunjukkan hasil yang bervariasi dan berfluktuasi. Terjadi peningkatan dan penurunan pada masing-masing rasio keuangan di tiap perusahaan yang menjadi sampel. Sesudah dilakukan merger atau akuisisi terjadi penurunan pada rasio keuangan yang diwakili oleh Net Profit Margin (NPM), Return on Investment (ROI), Return on Asset (ROA), Return on Equity (ROE), Total Asset Turn Over (TATO), Fixed Asset Turn Over (FATO), Earning Per Share (EPS), Price Earning Ratio (PER), Current Ratio (CR), dan Quick Ratio (QR). Sedangkan untuk rasio Debt Ratio (DR) serta Debt to Equity Ratio (DER) mengalami peningkatan, yang artinya porsi aktiva yang dibiayai oleh hutang yang berasal dari kreditor juga meningkat dan mengancam ekuitas perusahaan.

Pihak perusahaan disarankan untuk mempertimbangkan lebih dahulu ketika akan melakukan merger atau akuisisi, sehingga diharapkan perusahaan mendapatkan keuntungan yang maksimal di masa mendatang. Selain itu, pihak perusahaan juga perlu melakukan pertimbangan dan berhati-hati dalam menyikapi kegiatan merger atau akuisisi, karena belum dapat dipastikan bahwa merger atau akuisisi memberikan dampak positif bagi perusahaan.

\section{REFERENSI}

Ahmed, F., Manwani, A., \& Ahmed, S. (2018). Merger \& acquisition strategy for growth, improved performance and survival in the financial sector. Jurnal Perspektif Pembiayaan Dan Pembangunan Daerah, 5(4), 196-214.

Akben-Selcuk, E., \& Altiok-Yilmaz, A. (2011). The impact of mergers and acquisitions on acquirer performance: Evidence from Turkey. Business and Economics Journal, 22, 1-8. 
Albizzatti, N., \& Sias, D. (2004). New tricks for the old deal pro. MERGERS AND ACQUISITIONS-PHILADELPHIA-, 39, 28-35.

Bolbanabad, A. M., Mosadeghrad, A. M., Arab, M., \& Majdzadeh, R. (2017). Impact of merger and acquisition on university performance. Archives of Iranian Medicine, 20(8), 0-0.

Bursa Efek Indonesia. Diunduh pada 31 Juli 2017, www.idx.co.id.

Gadiesh, O., Ormiston, C., \& Rovit, S. (2003). Achieving an M\&A's strategic goals at maximum speed for maximum value. Strategy $\mathcal{E}$ Leadership.

Gugler, K., Mueller, D. C., Yurtoglu, B. B., \& Zulehner, C. (2003). The effects of mergers: An international comparison. International Journal of Industrial Organization, 21(5), 625-653.

Harari, O. (1997). Curing the M\&A madness. Management Review, 86(7), 53.

IMAA (2020) https://imaa-institute.org/mergers-and-acquisitions-statistics/. Diakses pada tanggal 16 Mei 2020.

Ismail, T. H., Abdou, A. A., \& Annis, R. M. (2011). Review of literature linking corporate performance to mergers and acquisitions. The Review of Financial and Accounting Studies, 1(1), 89-104.

Komisi Pengawas Persaingan Usaha. Diunduh pada 31 Juli 2017, www.kppu.go.id.

Laiman, L., \& Hatane, S. E. (2017). Analisis dampak merger dan akuisisi terhadap kinerja keuangan pada perusahaan non keuangan yang terdaftar di Bursa Efek Indonesia periode tahun 2007-2014. Business Accounting Review, 5(2), 517-528.

Lau, B., Proimos, A., \& Wright, S. (2008). Accounting measures of operating performance outcomes for Australian mergers. Journal of Applied Accounting Research.

Mahesh, R., \& Prasad, D. (2012). Post-merger and acquisition financial performance analysis: A case study of select Indian airline companies. International Journal of Engineering and Management Sciences, 3(3), 362-369.

Motis, J. (2007). Mergers and acquisitions motives. Toulouse School of Economics EHESS (GREMAQ) and University of Crete. Retrieved from Economics. Soc. Uoc. Gr/Wpa/Docs/Paper2mottis. Pdf.

Oduro, I. M., \& Agyei, S. K. (2013). Mergers \& acquisition and firm performance: Evidence from the Ghana Stock Exchange. Research Journal of Finance and Accounting, 4(7), 99-107.

Perwito, Wibowo, L. A., \& Hamdani, D. (2020). Penciptaan Nilai Perusahaan: Spesial Isu Merger dan Akuisisi Perusahaan Publik di Indonesia. Fair Value: Jurnal Ilmiah Akuntansi Dan Keuangan, 3(1), 85-93.

Rozen-Bakher, Z. (2018). Comparison of merger and acquisition (M\&A) success in horizontal, vertical and conglomerate M\&As: Industry sector vs. Services sector. The Service Industries Journal, 38(7-8), 492-518.

Setiawan, I. P. D. A., \& Rasmini, N. K. (2018). Analisis Perbandingan Kinerja Keuangan Perusahaan Sebelum dan Sesudah Merger dan Akuisisi Periode 2011-2014. E-Jurnal Akuntansi, 24(1), 687-714.

Van Horne, J. C., \& Wachowicz Jr, J. M. (2013). Prinsip-Prinsip Manajemen Keuangan Buku 1. Edisi Ketiga Belas. Jakarta: Salemba Empat. 
Yeh, T., \& Hoshino, Y. (2002). Productivity and operating performance of Japanese merging firms: Keiretsu-related and independent mergers. Japan and the World Economy, 14(3), 347-366.

Zuhri, S., Fahlevi, M., Abdi, M. N., Irma, D., \& Maemunah, S. (2020). The impact of merger and acquisition on financial performance in Indonesia. Journal of Research in Business, Economics, and Education, 2(1). 